\title{
Release of symbiotic algae by tropical sea anemones and corals after cold shock
}

\author{
L. Muscatine, D. Grossman*, J. Doino \\ Department of Biology, University of California, Los Angeles, California 90024, USA
}

\begin{abstract}
When the tropical sea anemones Aiptasia pulchella and A. pallida are exposed briefly to subnormal temperatures (i.e. cold shocked), and then rewarmed to ambient temperatures, they release substantial numbers of zooxanthellae. Release consists of dissociation of zooxanthellae from the endoderm as a result of cold shock, and expulsion of zooxanthellae from the coelenteron after rewarming. Release varies with cold shock temperature and duration. A 4 h cold shock at $4{ }^{\circ} \mathrm{C}$ evokes release of 40 to $55 \%$ of the zooxanthellae after $12 \mathrm{~h}$, and in some cases up to $87 \%$ in $72 \mathrm{~h}$. As shock temperature increases to about $16^{\circ} \mathrm{C}$, fewer zooxanthellae are released. Above about $16^{\circ} \mathrm{C}$, and up to $28^{\circ} \mathrm{C}$, the response is similar to that of unshocked controls. Release is greater at 4 and $10^{\circ} \mathrm{C}$ if the duration of exposure is extended up to about 7 to $8 \mathrm{~h}$. Longer cold shock duration elicits no additional release. Release varies with rewarming temperature. Rewarming to at least $17.5^{\circ} \mathrm{C}$ is essential for evoking maximum expulsion of zooxanthellae. Eleven species of scleractinian corals from the Seychelles Is., St. Croix, and Hawaii also released zooxanthellae after a $4 \mathrm{~h}$ cold shock between 12 and $18{ }^{\circ} \mathrm{C}$. Release at $12^{\circ} \mathrm{C}$ ranged from about 20 to $75 \%$ after $12 \mathrm{~h}$, depending on species, geographic location, and duration of cold shock. The ecological implications of cold shock on release of zooxanthellae are discussed in terms of upwelling and seasonal low temperatures. The mechanism by which low temperature evokes release is unknown, but could involve thermotropic effects on host cell membranes.
\end{abstract}

\section{INTRODUCTION}

Coral reef anthozoans invariably contain relatively large populations of symbiotic dinoflagellates ('zooxanthellae'). The zooxanthellae reside in cells of the host endoderm (Glider et al. 1980). They carry out photosynthesis, accelerate calcification by corals, and mediate nutrient flux between the environment and the host animals. In so doing, they contribute to the fitness of their host and to the primary productivity of the communities in which they reside (D'Elia \& Wiebe 1990, Muscatine 1990)

Under optimal environmental conditions the population density of symbiotic dinoflagellates is usually stable, and its magnitude is often predictable (Drew 1972, Muscatine et al. 1986). However, under some conditions it changes dramatically. For example, an increase in ambient nutrient concentration causes a 2fold increase in symbiont population density in the Indo-Pacific coral Stylophora pistillata (Hoegh-Guldberg \& Smith 1989, Muscatine et al. 1989, Dubinsky et

\footnotetext{
- Present address: Stanford University Medical School, Palo Alto, California 94305, USA
}

al. 1990), while coincidental with elevated temperatures there is a decrease in symbiont population density in many reef corals, often with drastic results to the host (see for example Jaap 1979, Lasker et al. 1984, Harriot 1985, Hoegh-Guldberg \& Smith 1989, Porter et al. 1989, Brown \& Suharsono 1990, Cook et al. 1990, Gates 1990, Glynn \& D'Croz 1990, Goreau \& MacFarlane 1990, Jokiel \& Coles 1990, Lesser et al. 1990, Szmant \& Gassman 1990, Williams \& Bunkley-Williams 1990).

Sustained exposure to subnormal temperatures also affects zooxanthellae population density. During upwelling episodes and seasonal lows many scleractinian corals not only release zooxanthellae but also grow slowly, cease feeding and die (Mayer 1914, 1916, Shinn 1966, 1976, Glynn \& Stewart 1973, Glynn 1977. Jokiel \& Coles 1977, Jaap 1979, Roberts et al. 1982, Walker et al. 1982, Porter 1986, Coles \& Fadlallah 1990, Glynn \& D'Croz 1990).

Whereas some investigations have described qualitative effects of low temperature stress on zooxanthellae population density (Coles 1973 in Jaap 1979, Glynn \& $D^{\prime}$ Croz 1990), few have addressed the mechanism by which low temperature destabilizes algae-cnidarian 
symbioses. Steen \& Muscatine (1987) found that when the tropical sea anemone Aiptasia pulchella is given a brief cold shock $\left(4^{\circ} \mathrm{C}, 1\right.$ to $\left.4 \mathrm{~h}\right)$, and then returned to normal maintenance temperature $\left(25^{\circ} \mathrm{C}\right)$, there is an immediate and substantial release of zooxanthellae. About $50 \%$ of the algae are released in $12 \mathrm{~h}$ and about $97 \%$ after $72 \mathrm{~h}$. The host seems otherwise unaffected and survives in the laboratory if fed. The response of $A$. pulchella to cold shock provides a rapid quantitative bioassay for investigating the mechanism by which low temperature stress evokes the release of zooxanthellae. Using this bioassay in conjunction with time-lapse videos of A. pulchella, Hoegh-Guldberg (1989) demonstrated that, after a brief cold shock, zooxanthellae initially accumulate in the coelenteron, and then periodically leave through the actinopharynx as large pellets, along with loose cells, propelled by activity of cilia and muscles. Release may be viewed as a 2-phase process: (1) dissociation from the endoderm, and (2) expulsion from the coelenteron.

In this paper, to gain insight into the susceptibility of coral reef anthozoans to low temperature destabilization, we describe the range of subnormal temperatures that elicits release (i.e. dissociation from endoderm and expulsion from coelenteron) of zooxanthellae from 2 species of the tropical sea anemone Aiptasia. We demonstrate that transient cold shock also causes release of zooxanthellae from selected scleractinian corals. In addition we provide quantitative data on the kinetics of release as a function of cold shock temperature and duration. The cellular aspects of release are described by Gates, Baghdasarian \& Muscatine (unpubl.).

\section{METHODS}

Collection and maintenance of organisms. The sea anemone Aiptasia pulchella was collected from sea water tables and the lagoon at the Hawaii Institute of Marine Biology (HIMB), Coconut Island, Oahu, and transported to the laboratory at the University of California at Los Angeles (UCLA) in transparent plastic screw-cap jars. Anemones were then maintained in finger bowls or in recirculating aquaria. These were kept in incubators at $25^{\circ} \mathrm{C}$ on a $12 \mathrm{~L}: 12 \mathrm{D}$ photoperiod at an irradiance of $40 \mu$ Einsteins $\mathrm{m}^{-2} \mathrm{~s}^{-1}$ provided by $40 \mathrm{~W}$ fluorescent lights. They were fed newly hatched Artemia 3 times each week and they reproduced by pedal laceration. Aiptasia pallida was collected from mangrove roots at Salt River Bay, St, Croix, USVl, and maintained in running sea water aquaria at the West Indies Laboratory (WIL).

Corals were collected by snorkel or SCUBA at various sites and depths (see Table 1) in the Seychelles Is., Indian Ocean, during a joint Soviet-American-Viet- namese marine science expedition aboard the RV 'Aleksandr Nesmeyanov' in February and March 1989; at WIL, St. Croix, in August 1989; and at HIMB, Hawaii, in February 1991. Corals were placed in opaque plastic containers at depth of collection, transported to aquaria within $1 \mathrm{~h}$ and maintained in running sea water at ambient temperature for no longer than $3 \mathrm{~d}$. In the Seychelles, the aquaria were stationed on the deck of the RV 'Aleksandr Nesmeyanov' and fitted with screens to admit 7,17 or $100 \%$ of ambient irradiance. Corals were maintained at a shade level which most closely approximated that of their habitat. At HIMB and WIL, corals were kept in outdoor sea water tables in shade.

Cold shock bioassay. The bioassay generally followed the protocol of Steen \& Muscatine (1987), but differed in detail for anemones and corals. Organisms were transferred from sea water at ambient temperature to sea water pre-chilled to subnormal temperatures between 4 and $20^{\circ} \mathrm{C}$ and maintained for $4 \mathrm{~h}$ in the dark, usually between 16:00 and 20:00 h. They were then rewarmed by replacing the chilled sea water with water at ambient temperature (Aiptasia spp.: $28^{\circ} \mathrm{C}$ at WIL, $24^{\circ} \mathrm{C}$ at HIMB and UCLA; corals: $28^{\circ} \mathrm{C}$ in Seychelles; $20.5^{\circ} \mathrm{C}$ at WIL, $24^{\circ} \mathrm{C}$ at HIMB) and then assayed $12 \mathrm{~h}$ later for release of zooxanthellae. In some experiments we varied either the cold shock temperature, the cold shock duration, or the rewarming temperature, while holding the other parameters constant.

Aiptasia spp. The effect of cold shock on the release of zooxanthellae by Aiptasia spp. was determined by placing from 1 to 5 anemones in each of 6 plastic scintillation vials containing $5 \mathrm{ml}$ of chilled sea water. The vials were kept at low temperature in the dark in the reservoir of a refrigerated circulator (Lauda Model $\mathrm{K}-2 / \mathrm{RD}$ ) for $4 \mathrm{~h}$. The sea water was then removed from the vials and replaced with $5 \mathrm{ml}$ sea water at ambient temperature and the vials were returned to incubators (UCLA) or floated in a small rack in a maintenance aquarium (WIL). Anemones similarly treated but kept at ambient temperature served as controls. After incubation for $12 \mathrm{~h}$ the sea water was decanted from the vials and saved and combined with fresh sea water used to rinse the vials and anemones. Each anemone was then homogenized in a Teflon-glass tissue homogenizer. Release was quantified by counting zooxanthellae in samples of the sea water and the anemone homogenate with a haemacytometer The number of zooxanthellae expelled into the sea water was expressed as the percent of total zooxanthellae (sea water plus homogenate).

In some cases, particularly when anemones were small and release was minimal, the zooxanthellae in sea water and homogenates were quantified by relative chlorophyll fluorescence (Meints \& Pardy 1980). 
Samples of released zooxanthellae and animal homogenates were passed through glass fiber filters (Whatman GF/C). The filters were ground in $100 \%$ acetone with a motor-driven Teflon-glass tissue grinder and then centrifuged. The supernatant acetone extracts were filtered again to remove GF/C filter particles. The acetone extract was then analysed with a Turner (Model 112) digital fluorimeter fitted with a 5-60 excitatory filter and 2-64 barrier filter. The number of zooxanthellae released into the sea water was expressed as a percentage of the total relative fluorescence (sea water plus homogenate).

In some experiments, to determine the kinetics of release of zooxanthellae, we assayed periodically for release up to $214 \mathrm{~h}$ after cold shock. Zooxanthellae released during each sampling interval was expressed as a cumulative percentage of the total zooxanthellae.

To determine if the kinetics of release could be expressed by a specific rate constant, we used a least squares estimation procedure (Cornell \& Speckman 1967) to fit a straight line through the origin of the graph of $\log _{e}$ (per cent algae retained) vs time. There was a significant deviation of observed data from expected data, suggesting that the specific rate of release was not constant. To simplify the expression of kinetics of release, we used an estimate of the average rate of release (percent $\mathrm{h}^{-1}$ ) over the first $24 \mathrm{~h}$ after cold shock.

Corals. The effect of cold shock on release of zooxanthellae by corals was determined by placing small intact colonies, or pieces of subdivided colonies, in jars (11) or 1 to $3 \mathrm{~cm}$ branch tips positioned upright in specially constructed plastic racks. Jars and racks were placed in a refrigerated aquarium aboard the RV 'Aleksandr Nesmeyanov' in the Seychelles. In St. Croix and Hawail racks were placed in $300 \mathrm{ml}$ clear plastic cylinders fitted with water jackets. The desired temperature was maintained with a refrigerated circulator (Lauda Model K-2/RD). Cold shock temperatures ranged from 12 to $18^{\circ} \mathrm{C}\left( \pm 0.5^{\circ} \mathrm{C}\right)$. After the cold shock incubation, corals (except those from Hawaii) were returned to aquaria at normal temperatures (i.e. rewarmed) and assayed $12 \mathrm{~h}$ later. As corals in Seychelles and St. Croix were rewarmed in running sea water, it was not possible to measure the response to cold shock by collecting and counting the released zooxanthellae as we had done with Aiptasia. Instead, at the end of the rewarming period the population density of zooxanthellae remaining in the corals was compared to controls kept at normal temperatures and expressed as a per cent of the control value.

Release of zooxanthellae from corals was estimated from one of several quantitative parameters such as number of cells, total chl $a$, or total chl $c_{2}$, normalized to weight of skeleton, surface area, or number of polyps. The choice of parameters was dictated by the extent to which the coral tissue and skeletal morphology lent itself to a given measurement (Table 1).

As Hawaiian corals lived perfectly well after cold shock and rewarming in standing sea water, they were assayed in the same manner as with Aiptasia. Colonies were collected from Kaneohe Bay at a depth of $1 \mathrm{~m}$. Branch tips ( 1 to $2 \mathrm{~cm}$ length) were chilled as described above, generally between 16:00 and 20:00 h. Branch tips were then transferred individually to beakers containing $20 \mathrm{ml}$ sea water at ambient temperature. Beak-

Table 1. Background data for corals used in this study

\begin{tabular}{|c|c|c|c|c|}
\hline Species & Collection location & $\begin{array}{l}\text { Collection depth } \\
\text { (m) }\end{array}$ & $\begin{array}{l}\text { Рarameter } \\
\text { measured }^{a}\end{array}$ & $\begin{array}{l}\text { Values for controls } \\
\qquad(\bar{X} \pm S D)(n)\end{array}$ \\
\hline \multicolumn{5}{|c|}{ Seychelles Is. } \\
\hline Acropora sp. & Astove Atoll & 7 & 1 & $41.11 \pm 5.33(2)$ \\
\hline Fungia sp. & Astove Atoll & $3-7$ & 2 & $17.66 \pm 4.85(2)$ \\
\hline Pocillopora damicornis & Cosmoledo Atoll & $3-10$ & 1 & $41.53 \pm 3.71(2)$ \\
\hline Seriatopora hystrix & St. Joseph Reef & 2 & 1 & $19.74 \pm 4.54(4)$ \\
\hline \multirow[t]{4}{*}{ Seriatopora caliendrum } & Praslin Is. & 2 & 2 & $6.27 \pm 1.87(7)$ \\
\hline & & 36 & 2 & $13.66 \pm 2.40(7)$ \\
\hline & & 2 & 3 & $1.71 \pm 0.03\{2\}$ \\
\hline & & 36 & 3 & $2.18 \pm 0.22(9)$ \\
\hline Stylophora pistillata & Mahe Is. & $4-7$ & 3 & $1.79 \pm 0.39(9)$ \\
\hline \multicolumn{5}{|c|}{ St. Croix } \\
\hline Acropora cervicornis & Teague Bay & $3-12$ & 4 & $0.11 \pm 0.01(3)$ \\
\hline Dendrogyra cylindrus & Teague Bay & $3-12$ & 5 & $3.33 \pm 2.49(14)$ \\
\hline Eusmilia fastigiata & Teague Bay & $3-12$ & 3 & $2.73 \pm 0.94(7)$ \\
\hline Montastraea annularis & Teague Bay & $3-12$ & 5 & $3.01 \pm 0.28$ \\
\hline Porites porites & Teague Bay & $3-12$ & 3 & $2.93 \pm 0.98(8)$ \\
\hline
\end{tabular}


ers were positioned in sea water tables for temperature control overnight. Released algae were recovered after $12 \mathrm{~h}$, counted, and expressed as percent of total algae.

Number of zooxanthellae was determined with a haemacytometer after removal of tissue from skeletons with a Water-Pik. Chlorophylls $a$ and $c_{2}$ were obtained by repeated extraction of whole pieces of coral with $100 \%$ acetone, followed by application of the spectrophotometric method of Jeffrey \& Humphrey (1975). After removal of tissue, skeletal dry weight was determined with a Techniprot torsion balance to the nearest $0.1 \mathrm{mg}$. Surface area of skeletons was determined by the aluminum foil method (Marsh 1970). Number of polyps was determined by visual census.

\section{RESULTS}

\section{Aiptasia spp.}

Variable shock temperature, constant shock duration, constant rewarming temperature

To determine the range of subnormal temperatures that elicit release of zooxanthellae, we exposed Aiptasia spp. to temperatures from 4 to $20^{\circ} \mathrm{C}$ for $4 \mathrm{~h}$, then rewarmed them to normal ambient temperature and assayed for release after $12 \mathrm{~h}$. Fig. 1 shows that a $4{ }^{\circ} \mathrm{C}$ cold shock caused A. pulchella and A. pallida to release between 40 and $55 \%$ of their zooxanthellae. At higher shock temperatures, concomitantly fewer algae were released. Above $16{ }^{\circ} \mathrm{C}$ less than $10 \%$ of the algae were released and the response approached that of unshocked controls at 24 and $28^{\circ} \mathrm{C}$.

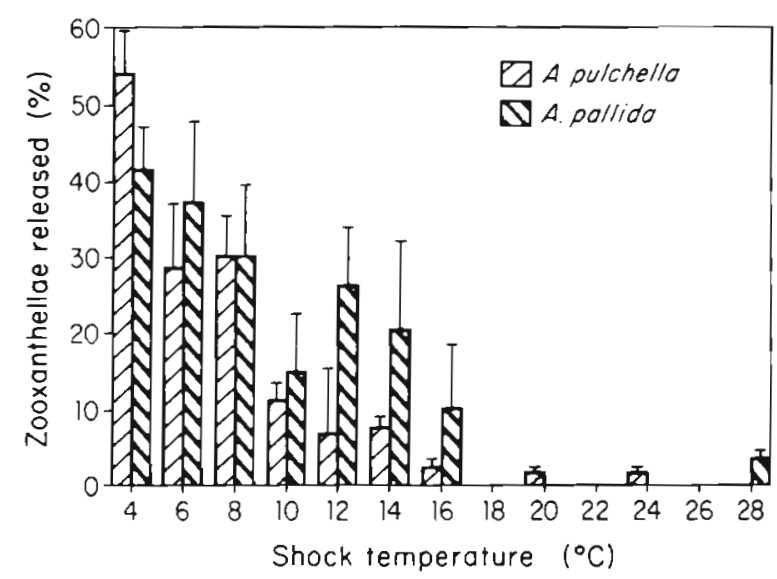

Fig. 1. Aiptasia spp. Effect of cold shock temperature on the release of zooxanthellae. A. pulchella and A. pallida were incubated at various cold shock temperatures for $4 \mathrm{~h}$, followed by rewarming at 25 and $28^{\circ} \mathrm{C}$ respectively, for $12 \mathrm{~h}$. Values are means \pm one standard deviation (A. pulchella $\mathrm{n}=3 ; \mathrm{A}$. pallida $\mathrm{n}=6$ ). Data for $\mathrm{A}$. pallida at 20 and $24^{\circ} \mathrm{C}$ missing due to onset of Hurricane Hugo and destruction of the West Indies Laboratory

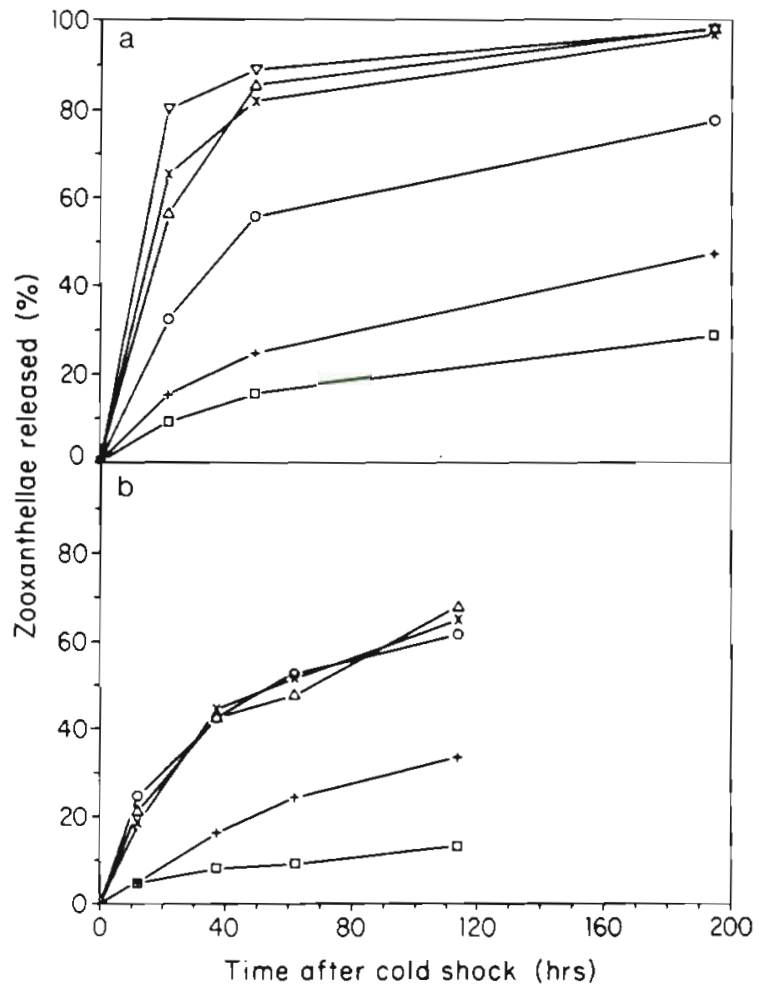

Fig. 2. Aiptasia pulchella. Effect of duration of cold shock at (a) $4{ }^{\circ} \mathrm{C}$ and (b) $10^{\circ} \mathrm{C}$ on release of zooxanthellae. Groups of 5 anemones each were incubated at $4{ }^{\circ} \mathrm{C}$ for $0.5 \mathrm{~h}(+), 1 \mathrm{~h}(0)$, $2.5 \mathrm{~h}(\Delta), 4 \mathrm{~h}(\times)$, and $7.5 \mathrm{~h}(\nabla)$, and at $10^{\circ} \mathrm{C}$ for $1 \mathrm{~h}(+), 2 \mathrm{~h}(\Delta)$, $3 \mathrm{~h}(0)$, and $4 \mathrm{~h}(x)$, followed by rewarming at $25^{\circ} \mathrm{C}$

(घ) Control $\left(25^{\circ} \mathrm{C}\right)$. Data for each group of 5 anemones were pooled for each point

Constant shock temperature, variable shock duration, constant rewarming temperature

To determine the effect of duration of cold shock on release of zooxanthellae, we exposed Aiptasia pulchella to either 4 or $10^{\circ} \mathrm{C}$ for up to $7.5 \mathrm{~h}$, followed by rewarming at normal ambient temperatures. We then assayed periodically for up to $214 \mathrm{~h}$ after cold shock to determine the kinetics of release of zooxanthellae. Representative data are shown in Fig. 2. The cumulative percentage of zooxanthellae released varied with duration of a $4{ }^{\circ} \mathrm{C}$ cold shock (Fig, 2a). Release was relatively low when the duration of cold shock was only $0.5 \mathrm{~h}$, but was greater if duration of cold shock was increased to $1 \mathrm{~h}$, and greater still at a duration of $2.5 \mathrm{~h}$. A duration of 4 or $7.5 \mathrm{~h}$ elicited no additional release of zooxanthellae. Anemones exposed to $4{ }^{\circ} \mathrm{C}$ for $7.5 \mathrm{~h}$ appeared healthy, but extending the duration of a $4{ }^{\circ} \mathrm{C}$ cold shock to $12 \mathrm{~h}$ proved lethal to $A$. pulchella.

Although the cold shock is transient, the release of zooxanthellae continued for up to $8 \mathrm{~d}$. By that time the anemones cold shocked for 2.5 to $7.5 \mathrm{~h}$ had lost up to $97.5 \%$ of their algae 
Fig. $2 b$ shows that the cumulative percentage of zooxanthellae released varied with duration of a $10^{\circ} \mathrm{C}$ cold shock. Release was relatively low after a $1 \mathrm{~h}$ cold shock, but was greater after $2 \mathrm{~h}$. A duration of 3 or $4 \mathrm{~h}$ elicited no additional release.

To determine if zooxanthellae were released during the cold shock period, and noting that Aiptasia pulchella could endure longer exposure at $10^{\circ} \mathrm{C}$, we extended the $10^{\circ} \mathrm{C}$ cold shock to 12 and $18 \mathrm{~h}$, followed by rewarming. In these experiments we assayed at the end of the cold shock period (i.e. at $0 \mathrm{~h}$ ) and then periodically up to $60 \mathrm{~h}$. Fig. 3 shows that release was minimal during the extended cold shock period but substantial upon rewarming to normal temperatures. However, microscopic observation of anemones indicated that zooxanthellae accumulated in the coeloenteron during the cold shock period. To quantify this observation, 2 sets of anemones were cold shocked at $10^{\circ} \mathrm{C}$. After $4 \mathrm{~h}$ one set was rewarmed to $25^{\circ} \mathrm{C}$ for $12 \mathrm{~h}$ The second set was kept at $10^{\circ} \mathrm{C}$ for $12 \mathrm{~h}$. Controls were kept at $25^{\circ} \mathrm{C}$ for $16 \mathrm{~h}$. Release of zooxanthellae was bioassayed as before, but in addition, both sets of anemones were bisected longitudinally and the zooxanthellae in the coelenteron were recovered by rinsing with a pipette and counted. Additionally, trials were carried out on both small and large anemones. Table 2 shows that those rewarmed for $12 \mathrm{~h}$ after cold shock released a total of $17.3 \%$ and $36.8 \%$ of their zooxanthellae, respectively. Few zooxanthellae were recovered from the coelenteron. In contrast, anemones maintained at $10^{\circ} \mathrm{C}$ for $16 \mathrm{~h}$ released few zooxanthellae to the sea water, but had $18 \%$ and $36 \%$ of their

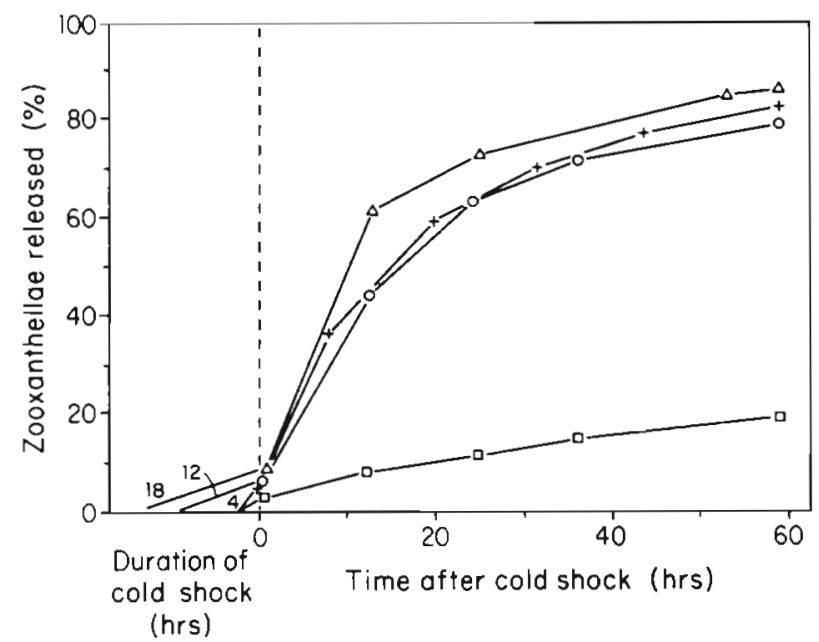

Fig. 3. Aiptasia pulchella. Effect of extending duration of cold shock at $10^{\circ} \mathrm{C}$ on the release of zooxanthellae. Three groups of 4 anemones each incubated at $10^{\circ} \mathrm{C}$ for $4 \mathrm{~h}(+), 12 \mathrm{~h} \mathrm{(o)}$. and $18 \mathrm{~h}(\Delta)$, followed by rewarming at $25^{\circ} \mathrm{C}$. (a) Control. Data for each group of 4 anemones pooled. Values are means $(n=3)$
Table 2. Aiptasia pulchella. Percent release of zooxanthellae by small and large anemones during and after cold shock. $\left(\mathrm{A}=16 \mathrm{~h}, 10^{\circ} \mathrm{C} ; \mathrm{B}=4 \mathrm{~h}, 10^{\circ} \mathrm{C} ; 12 \mathrm{~h}, 25^{\circ} \mathrm{C} ; \mathrm{C}=\right.$ control, $16 \mathrm{~h}$, $25^{\circ} \mathrm{C}$. Average total number of zooxanthellae per anemone in Trial $1=1.87 \times 10^{6} ;$ in Trial $2=3.89 \times 10^{6}$ )

\begin{tabular}{|lrrr|}
\hline Treatment & $\begin{array}{c}\text { Zooxanthellae } \\
\text { expelled to } \\
\text { sea water }\end{array}$ & $\begin{array}{c}\text { Zooxanthellae } \\
\text { in coelenteron }\end{array}$ & $\begin{array}{c}\text { Total } \\
\text { zooxanthellae } \\
\text { released }\end{array}$ \\
\hline Trial 1 & & & \\
A $(\mathrm{n}=2)$ & $0.9 \pm 1.0$ & $18.8 \pm 1.5$ & $19.7 \pm 0.4$ \\
B $(\mathrm{n}=3)$ & $12.8 \pm 4.6$ & $4.6 \pm 2.8$ & $17.3 \pm 7.3$ \\
C $(\mathrm{n}=2)$ & $3.8 \pm 3.8$ & $2.5 \pm 0.8$ & $6.3 \pm 4.7$ \\
Trial 2 & & & \\
A $(\mathrm{n}=4)$ & $2.1 \pm 1.3$ & $36.9 \pm 5.4$ & $39.0 \pm 6.2$ \\
B $(\mathrm{n}=4)$ & $28.9 \pm 8.2$ & $7.9 \pm 4.4$ & $36.8 \pm 9.3$ \\
C $(\mathrm{n}=2)$ & $1.8 \pm 0.5$ & $3.6 \pm 0.0$ & $5.4 \pm 0.5$ \\
\hline
\end{tabular}

zooxanthellae contained in the coelenteron. Release by controls was minimal. We interpret these data to mean that zooxanthellae dissociate from the endoderm during cold shock and that rewarming is required for expulsion from the coelenteron.

The average rate of release of zooxanthellae during the first $24 \mathrm{~h}$ after cold shock was estimated from data in Figs 2 \& 3, and plotted against duration of cold shock at 4 and $10^{\circ} \mathrm{C}$. Fig. 4 shows that the average rate of release was significantly greater at $4{ }^{\circ} \mathrm{C}$ than at $10^{\circ} \mathrm{C}$ (Student's $t$-test, $\mathrm{p}<0.005$ ). As duration of cold shock at $4{ }^{\circ} \mathrm{C}$ increased to between 6 and $7.5 \mathrm{~h}$, release approached a maximum value of $3.3 \% \mathrm{~h}^{-1}$. Both sets of data suggest that the effect of duration of cold shock on release of zooxanthellae may be saturable.

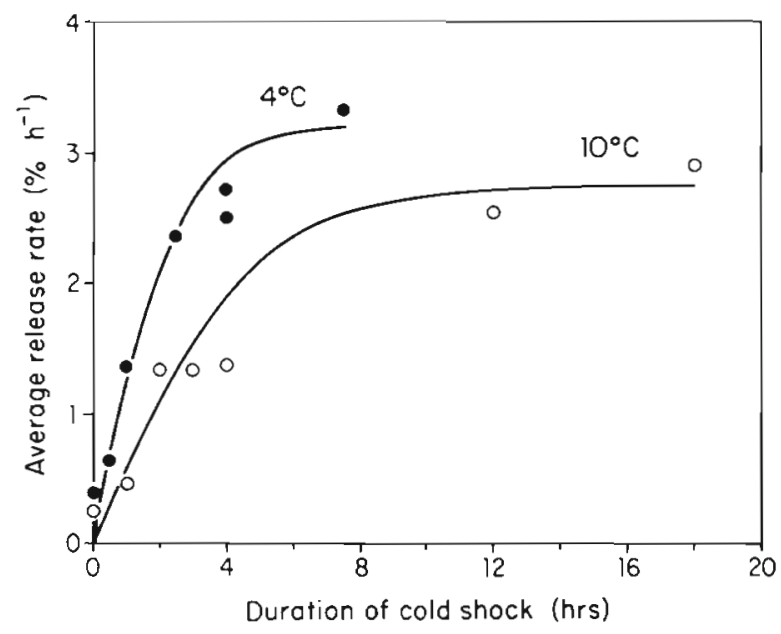

Fig. 4. Aiptasia pulchella. Effect of duration of cold shock at $4{ }^{\circ} \mathrm{C}(\bullet)$, and $10^{\circ} \mathrm{C}(0)$, followed by rewarming, on the average rate of release of zooxanthellae. Rates were computed from initial 24 h of release data in Figs. 2 \& 3 . Curves were fit using a nonlinear routine for rectangular hyperbolae. Initial slopes were compared using Student's $t$-test 
Constant shock temperature, constant duration, variable rewarming temperature

To determine the effect of varying the rewarming temperature on release of zooxanthellae, we exposed Aiptasia pulchella to $4{ }^{\circ} \mathrm{C}$ for $4 \mathrm{~h}$ followed by rewarming at temperatures between 8 and $17.5^{\circ} \mathrm{C}$ for $12 \mathrm{~h}$. Fig. 5 shows that release of zooxanthellae increased as the rewarming temperature increased. Release was significantly higher at $17.5^{\circ} \mathrm{C}$ than at the lower temperatures (Kruskal-Wallis nonparametric multiple comparison; $\mathrm{H}=8.4 ; \mathrm{p}<0.025 ;$ Zar 1984).

\section{Corals}

In a preliminary survey of a range of symbiotic cnidarians, we found that some species could not be bioassayed because of excessive production of mucus. Among those that could be bioassayed, the response to cold shock varied. None except Aiptasia spp. survived short-term exposure to temperatures below $12^{\circ} \mathrm{C}$. Others (unidentified gorgonians and zoanthids, and the sea anemones Lebrunea coralligens and Condylactis gigantea) did not survive the cold shock between 12 and $18{ }^{\circ} \mathrm{C}$. Others (Montastrea Cavernosa and Millepora complanata in St. Croix; Montipora verrucosa and Palythoa sp. in Hawaii) survived the cold shock but did not release zooxanthellae. Our observations were finally limited to 11 species of scleractinian corals which released zooxanthellae after cold shock between 12 and $18{ }^{\circ} \mathrm{C}$ (Table 1).

Variable shock temperature, constant shock duration, constant rewarming temperature

Fig. 6 shows that release of zooxanthellae by corals from the Seychelles and Hawail varied with cold shock temperatures between 12 and $18^{\circ} \mathrm{C}$ and with species. Release by Seychelles corals was most pronounced after cold shock at 12 and $14{ }^{\circ} \mathrm{C}$, barely detectable at 16 and $18^{\circ} \mathrm{C}$, and not detectable above $18^{\circ} \mathrm{C}$ (not shown). At $12{ }^{\circ} \mathrm{C}, 5$ species released between 20 and $70 \%$ of their zooxanthellae following a $4 \mathrm{~h}$ shock and $12 \mathrm{~h}$ rewarming. Pocillopora damicornis, Acropora sp. and Fungia sp. showed the greatest response. Except for Seriatopora caliendrum, which released maximally at $14{ }^{\circ} \mathrm{C}$, release tended to decrease as cold shock temperature increased. All of these corals survjved cold shock without any apparent damage and displayed expanded polyps and tentacles and sensitivity to mechanical stimulation.

To determine if habitat depth in the Seychelles influenced release of zooxanthellae after cold shock, we compared Seriatopora caliendrum collected from 2 and $36 \mathrm{~m}$. The habitat temperatures were 29.5 and $25.5^{\circ} \mathrm{C}$, respec-

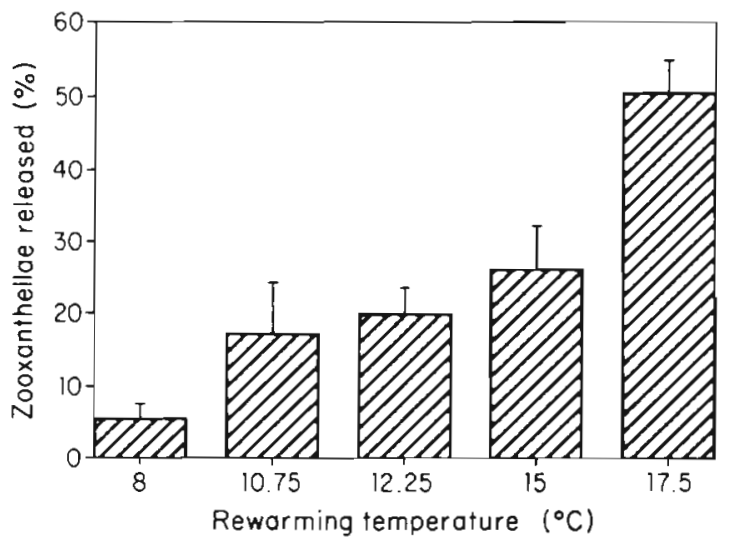

Fig. 5. Aiptasia pulchella. Effect of rewarming temperature on release of zooxanthellae. Two groups of 4 anemones each were incubated at $4{ }^{\circ} \mathrm{C}$ for $4 \mathrm{~h}$, followed by rewarming at various temperatures for $12 \mathrm{~h}$. Data for each group of 4 anemones pooled. Values are means \pm one standard deviation $(\mathrm{n}=2)$

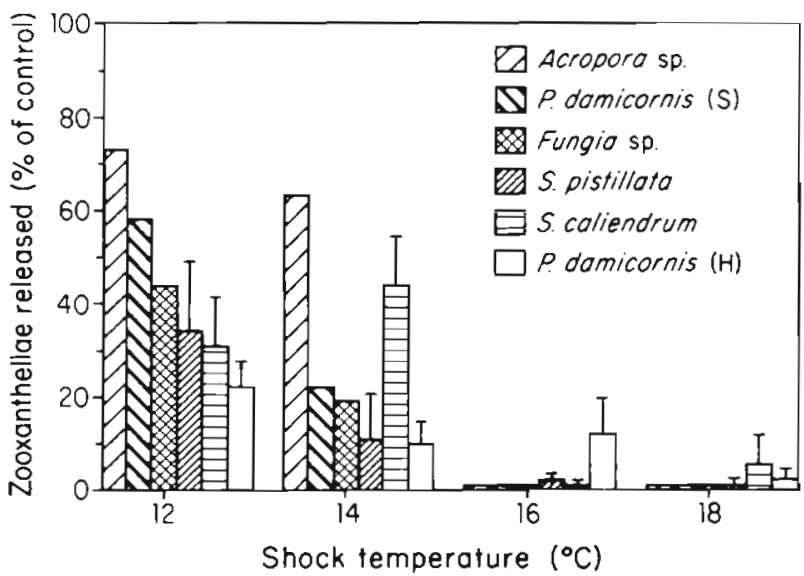

Fig. 6. Effect on corals of cold shock temperature on release of zooxanthellae. Corals from the Seychelles Islands (S) and Hawaii $(\mathrm{H})$ were incubated at various temperatures for $4 \mathrm{~h}$, followed by rewarming at ambient temperatures for $12 \mathrm{~h}$. For each value: Acropora sp., 6 tips pooled, Pocillopora damicornis (S), 6 tips pooled; Fungia sp., one $5 \mathrm{~cm}$ individual; Stylophora pistillata, 6 tips pooled $(\mathrm{n}=2)$; Seriatopora caliendrum, 6 tips pooled ( $\mathrm{n}=2)$; Pocillopora damicornis $(\mathrm{H}), 6$ individual tips $(n=6)$. Vertical bars are one standard deviation

tively. Fig. 7 shows that both sets released abundant zooxanthellae after a $12^{\circ} \mathrm{C}$ cold shock for $4 \mathrm{~h}$, and comparably fewer as cold shock temperature increased to $18^{\circ} \mathrm{C}$. Release by shallow and deep corals varied from one cold shock temperature to another, but not in any systematic way. Fig. 8 shows the kinetics of release by $S$. caliendrum during the rewarming period (i.e. up to $12 \mathrm{~h}$ after cold shock). The percentage of algae released by corals from both depths was again comparable and tended to increase with time after cold shock to about $40 \%$ at $12 \mathrm{~h}$. 


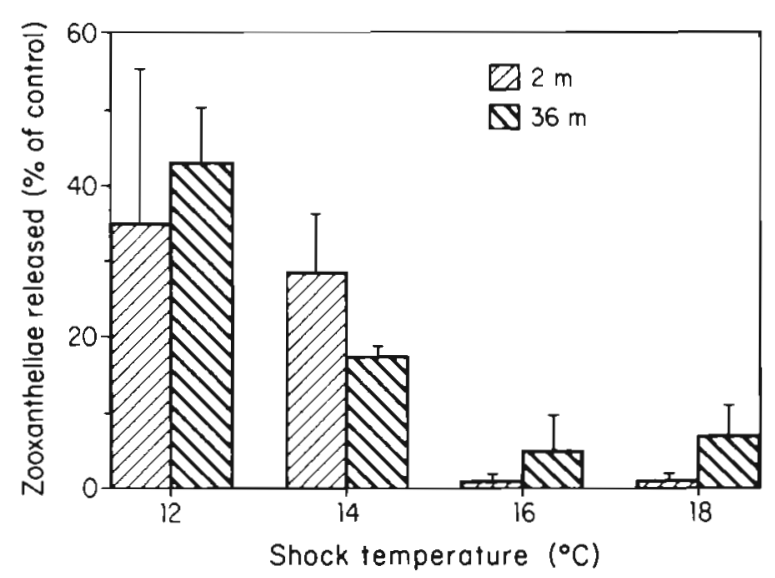

Fig. 7. Seriatopora caliendrum. Effect of habitat depth on release of zooxanthellae. Two groups of 6 tips each from $2 \mathrm{~m}$ and $36 \mathrm{~m}$ were incubated at various temperatures for $4 \mathrm{~h}$, followed by rewarming for $12 \mathrm{~h}$. Data for each group of 6 tips pooled. Values are means $\pm \mathrm{SD}(\mathrm{n}=2)$

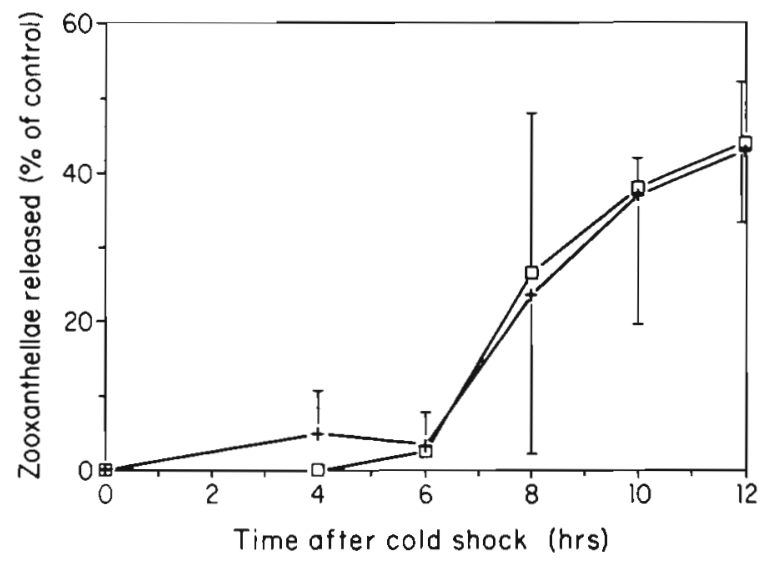

Fig. 8. Seriatopora caliendrum. Effect of cold shock on the rate of release of zooxanthellae. Two groups of 6 tips each from $2 \mathrm{~m} \mathrm{(+)}$ and $36 \mathrm{~m} \mathrm{(D)} \mathrm{were} \mathrm{incubated} \mathrm{at} 12{ }^{\circ} \mathrm{C}$ for $4 \mathrm{~h}$, followed by rewarming at $25^{\circ} \mathrm{C}$. Data for each group of 6 tips pooled. Values are means $\pm S D(n=2)$

Of the Hawaiian corals we investigated, only Fungia scutaria and Pocillopora damicornis responded to cold shock. Fungia released from 7 to $14 \%(n=2)$ of its zooxanthellae after a $4 \mathrm{~h}$ cold shock at $12{ }^{\circ} \mathrm{C}$, but further experiments were discontinued as production of mucus interfered with the bioassay at higher temperatures. Release by $P$, damicornis branch tips varied within and between colonies, depending on collection site and duration of maintenance. When all observations are pooled, release at $12,14,16$, and $18^{\circ} \mathrm{C}$ was $26.78 \pm 16.11 \% \quad(\mathrm{n}=18), 37.6 \pm 29.4 \% \quad(\mathrm{n}=12)$, $7.07 \pm 8.06 \%(n=12)$, and $11.1 \pm 13.2 \%(n=12)$ respectively, $12 \mathrm{~h}$ after cold shock. When branches from a single colony were subjected to cold shock immediately after collection, the magnitude of release was somewhat less and tended to decrease as shock
Table 3. Pocillopora damicornis. Kinetics of release of zooxanthellae (Hawaii) after a cold shock $\left(12^{\circ} \mathrm{C} ; 4\right.$ h) $(\bar{X} \pm S D, n=4)$

\begin{tabular}{|cc|}
\hline $\begin{array}{c}\text { Time after cold shock } \\
(\mathrm{h})\end{array}$ & $\begin{array}{c}\text { Zooxanthellae released } \\
(\%)\end{array}$ \\
\hline 1 & $0.75 \pm 0.46$ \\
2 & $1.35 \pm 0.45$ \\
6 & $2.28 \pm 0.44$ \\
9 & $3.60 \pm 0.77$ \\
18 & $10.55 \pm 5.74$ \\
24 & $14.20 \pm 6.95$ \\
\hline
\end{tabular}

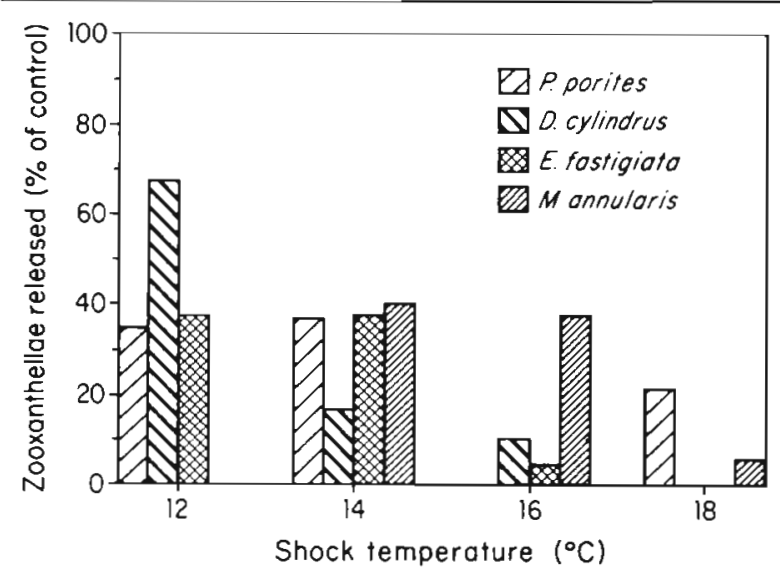

Fig. 9. Effect on corals of cold shock temperature on release of zooxanthellae. Corals from St. Croix were incubated at varjous temperatures for $4 \mathrm{~h}$, followed by rewarming at ambient temperatures for $12 \mathrm{~h}$. For each value: Porites porites, 6 tips pooled; Dendrogyra cylindrus, one $4 \mathrm{~cm}$ branch; Eusmilia fastigiata, 2 large polyps pooled; Montastraea annularis, one $5 \mathrm{~cm}^{2}$ piece

temperature increased (Fig. 6). Control branch tips maintained at ambient temperatures released less than $1.0 \%$ of their zooxanthellae. The kinetics of release by $P$. damicornis after a cold shock $\left(12^{\circ} \mathrm{C} ; 4\right.$ h) was followed for $24 \mathrm{~h}$. Table 3 shows that in this experiment the percentage of algae released was relatively low, but nevertheless increased with time after cold shock.

Corals from St. Croix also responded to cold shock between 12 and $18^{\circ} \mathrm{C}$ by releasing zooxanthellae (Fig. 9). The response decreased with increasing temperature in Dendrogyra cylindrus, Eusmilia fastigiata, Porites porites and Montastraea annularis. For unknown reasons, $P$. porties did not respond at $16{ }^{\circ} \mathrm{C}$, while Acropora cervicornis responded only at $18{ }^{\circ} \mathrm{C}$ and did not survive exposure to lower temperatures.

Constant shock temperature, variable shock duration, constant rewarming temperature

To determine the effect of duration of cold shock on release of zooxanthellae, we exposed Pocillopora 
Table 4. Pocillopora damicomis. Effect of duration of cold shock on release of zooxanthellae

\begin{tabular}{|lcc|}
\hline $\begin{array}{l}\text { Duration of } \\
\text { cold shock } \\
(\mathrm{h})\end{array}$ & $\begin{array}{c}\text { Zooxanthellae released } \\
\text { Seychelles }(\mathrm{n}=1) \\
\text { (\% of control) }\end{array}$ & $\begin{array}{c}\text { Hawaii }(\mathrm{n}=4) \\
(\%)\end{array}$ \\
\hline 1 & 14.5 & $26.4 \pm 7.95$ \\
2 & 25.7 & $27.0 \pm 7.53$ \\
3 & 44.0 & $30.0 \pm 4.94$ \\
4 & 78.4 & $55.0 \pm 9.47$ \\
\hline
\end{tabular}

damicornis from the Seychelles and Hawail to a $12{ }^{\circ} \mathrm{C}$ cold shock for 1 to $4 \mathrm{~h}$, followed by rewarming at ambient temperature and assay after $12 \mathrm{~h}$. Table 4 shows that release of zooxanthellae in both cases increased as duration of cold shock increased up to $4 \mathrm{~h}$. The increase was more pronounced in the Seychelles corals than in those from Hawaii.

\section{DISCUSSION}

\section{Aiptasia spp.}

Steen \& Muscatine (1987) found that transient cold shock at $4{ }^{\circ} \mathrm{C}$ evoked release of zooxanthellae from Aiptasia pulchella. The results of our investigation confirm their findings and show that a range of cold shock temperatures, followed by rewarming to ambient temperature, will evoke release of zooxanthellae from at least 2 species of Aiptasia (Fig. 1). The release response is inversely related to cold shock temperature and can be elicited by transient cold shock at or below about 15 to $16^{\circ} \mathrm{C}$.

Cold shock causes zooxanthellae to dissociate from the endoderm and, unless the anemones are rewarmed, they accumulate in the coelenteron (Table 2). Thus, Aiptasia pulchella while at $10^{\circ} \mathrm{C}$ for up to $18 \mathrm{~h}$ expels relatively few zooxanthellae. Apparently the activity of cilia and muscles at low temperature is insufficient to expel zooxanthellae from the coelenteron. For example, after a $4{ }^{\circ} \mathrm{C}$ cold shock the percentage of zooxanthellae released upon rewarming to $17.5^{\circ} \mathrm{C}$ is 10 times that of rewarming to $8^{\circ} \mathrm{C}$, and twice that of rewarming to $15^{\circ} \mathrm{C}$ (Fig. 5). It is not until the anemones are rewarmed to $25^{\circ} \mathrm{C}$ that release of zooxanthellae is immediate, substantial, and sustained. Rewarming is therefore essential for the mechanical expulsion of zooxanthellae from the coelenteron, and an integral part of the bioassay for release of zooxanthellae by the anemone, but it is not the primary stimulus for dissociation of zooxanthellae from the endoderm.

The rate of release of zooxanthellae varies with the duration of cold shock at 4 and $10^{\circ} \mathrm{C}$. The longer the duration, the greater the response. However, the effect of increased duration does appear to saturate at both temperatures. The data suggest that zooxanthellae may be released in stoichiometric amounts governed by some function of time and temperature. More detailed investigation will be required to confirm this suggestion.

Even though cold shock was transient, the release of algae persisted at normal ambient temperatures for about 8 d (e.g. Fig. 2). Persistent cell responsiveness after removal of stimuli is not unusual and has been observed in neural, endocrine, and cell proliferation systems (Alkon \& Rasmussen 1988).

The ecological implications of a transient cold shock as low as $4{ }^{\circ} \mathrm{C}$ on Aiptasia spp. are obscure. Although little is known of the field ecology and natural history of this genus, its members are unlikely to experience ambient temperatures of $4{ }^{\circ} \mathrm{C}$. On the other hand, Clark \& Jensen (1982) recorded temperatures as low as $10^{\circ} \mathrm{C}$ in the Florida habitat of $A$. pallida. They did not undertake a field study of any subsequent effect on the population, but they did establish that maintenance at $12{ }^{\circ} \mathrm{C}$ for 1 to $12 \mathrm{~d}$ in the laboratory significantly affected rates of carbon fixation and disposition of metabolites in the algae and the anemone. It would be desirable to know if transient cold shock has any effect at all on fitness of symbiont and host.

\section{Corals}

Previous studies show that sustained (i.e. $>1 \mathrm{~d}$ ) exposure to low temperature during upwelling or to seasonal temperature lows is harmful to some corals in specific geographic locations, causing decreased growth rate, and mortality (Glynn \& Stewart 1973, Coles \& Fadlallah 1990, Glynn \& D'Croz 1990). Even 9 h at 13 to $15^{\circ} \mathrm{C}$ is sufficient to kill some coral species (Mayer 1914). The quantitative effect of a very brief cold shock on the stability of a coral-zooxanthellae symbiosis has not been investigated until now

Our preliminary results showed that $4 \mathrm{~h}$ at temperatures below $12^{\circ} \mathrm{C}$ was lethal to the corals in this study, but 4 h at temperatures from 12 to $18^{\circ} \mathrm{C}$ followed by rewarming caused them to release zooxanthellae (Figs. 6 \& 9). They survive transient cold shock without any other apparent abnormal effects, at least for the several days of our observations. Long-term observations on survival or repopulation by zooxanthellae were not undertaken.

The response of corals to transient, short-term cold shock is apparently not a general one. Montastrea cavernosa and Millepora complanata from St. Croix and Montipora verrucosa and Palythoa sp. from Hawaii did not release zooxanthellae after a $4 \mathrm{~h}$ cold shock at $12{ }^{\circ} \mathrm{C}$. An explanation for the lack of response to cold shock among these corals, and the difference in sen- 
sitivity to cold shock between corals $\left(12\right.$ to $\left.18^{\circ} \mathrm{C}\right)$ and Aiptasia spp. (4 to $16^{\circ} \mathrm{C}$ ) may emerge once the mechanism which evokes release is described.

As with Aiptasia spp., the magnitude of release of zooxanthellae was, in most cases, inversely related to shock temperature in the 12 to $18^{\circ} \mathrm{C}$ range investigated. It varied with species, most notably in corals from St. Croix; with duration of cold shock, at least in Pocillopora damicornis (Table 3); and among congeners from different locations. Thus, Acropora sp. from $7 \mathrm{~m}$ in the Seychelles expelled 50 to $60 \%$ of its zooxanthellae in $12 \mathrm{~h}$ after a $4 \mathrm{~h}$ cold shock at $12^{\circ} \mathrm{C}$ (Fig. 6). Release was barely detectable at $18^{\circ} \mathrm{C}$. In contrast, Acropora sp. from 3 to $12 \mathrm{~m}$ in St. Croix released only $20 \%$ of its zooxanthellae at $18{ }^{\circ} \mathrm{C}$ and did not survive cold shock at lower temperatures (Fig. 9). Coral congeners from different locations and ambient temperature regimes also respond differently to heat shock (Coles et al. 1976, Cook et al. 1990). On the other hand, Seriatopora spp. from 2 and $36 \mathrm{~m}$ released comparable amounts of zooxanthellae after a 4 h cold shock at $12{ }^{\circ} \mathrm{C}$ (Fig. 7). As the specific habitat temperatures in the Seychelles at 2 and $36 \mathrm{~m}$ differ by only a few degrees, this result is not unexpected.

The various states of polyp expansion and contraction during rewarming may also affect expulsion and may account for some variation in release under a given set of conditions.

The ecological implications of sustained ( $>1$ d) low temperatures for the stability of coral-algae symbioses is well documented (see Glynn \& Stewart 1973, Coles \& Fadlallah 1990). On the other hand the implications of transient $(<1$ d) low temperatures are perhaps less obvious. For this reason the hydrological observations of Novozhilov et al. (1992) on the west coast of Coetivy Island in the Seychelles are notable. In January 1989 they observed that cold water $\left(15\right.$ to $\left.16^{\circ} \mathrm{C}\right)$, which

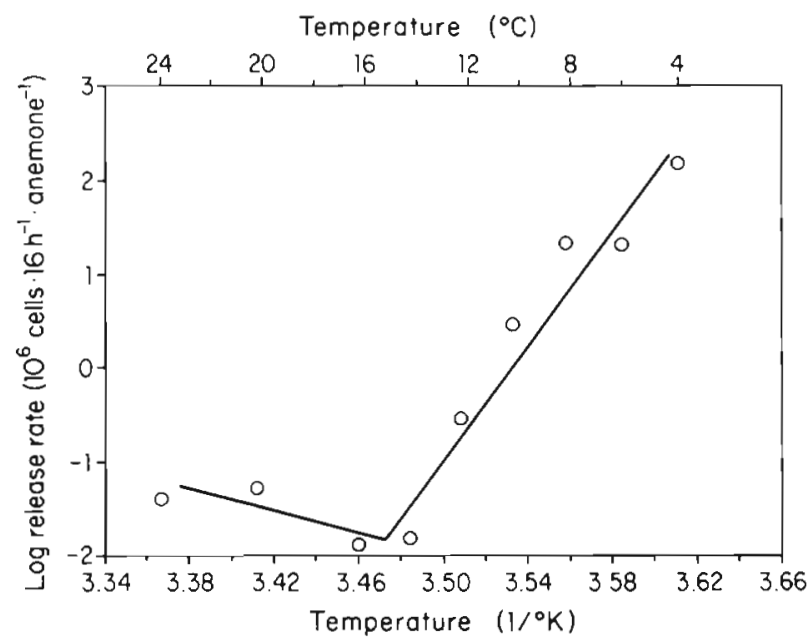

Fig. 10. Aiptasia pulchella. Arrhenius plot of rate of release of zooxanthellae vs temperature (data from Fig. 1) normally resides at 130 to $160 \mathrm{~m}$, upwelled to between 30 and $40 \mathrm{~m}$. The upwelling was cyclic, with a duration of $5 \mathrm{~h}$ at 30 to $40 \mathrm{~m}$. The intensity of the cycle varied, and resulted from both wind-driven and tidal forcing functions. They also noted that the depth limit of the corals at Coetivy was between 30 and $40 \mathrm{~m}$ while the abundant macrophytes extended to at least $60 \mathrm{~m}$. From these observations it is not unreasonable to conclude that the transient low temperature shock and rewarming may cause the corals to discharge zooxanthellae and that ultimately temperature, rather than light, may limit the depth distribution of these corals.

\section{Mechanism of release}

The mechanism by which cold shock might evoke release of zooxanthellae is not known. Nor is it known if release is a normal feature of cnidarian cellular dynamics (Stimson \& Kinzie 1991) which is accelerated by cold shock. Possible mechanisms include membrane thermotropism and protein denaturation (Watson \& Morris 1987). An Arrhenius plot of the Aiptasia pulchella temperature-release curve (Fig. 10) shows a break between 14 and $16{ }^{\circ} \mathrm{C}$. Such a discontinuity is consistent with the interpretation either that 2 different temperature-dependent phenomena are involved (Melchior \& Steim 1976) or that at temperatures at or below about 14 to $15^{\circ} \mathrm{C}$ there is a thermotropic effect on host cell membranes (Lagunoff \& Wan 1974, Quinn 1989) which leads to release of zooxanthellae.

Acknowledgements. We thank the captain and crew of the RV 'Aleksandr Nesmeyanov' for their support; Prof. E. Titlyanov for the invitation (to L.M.) to join the first Soviet-American-Vietnamese expedition in marine biology; P. Butorin for shipboard aquarium maintenance; $\mathrm{A}$. Lapshina for chlorophyll analyses; K. Bil', N. Latishev, A. Novozhilov, M. Littler, D. Littler, P. Dustan for valuable discussions; $B$. Preobrazhensky for identification of corals from the Seychelles; E. Gladfelter, W. Gladfelter, J. Bythell, M. Bythell and the West Indies Laboratory staff for help in innumerable ways, particularly in surviving Hurricane Hugo and its aftermath; D. Kreuger and S. Oberto for field and laboratory technical assistance at WIL and UCLA; S. Feinsilber, D. Shapiro, G. Baghdasarian, C. B. Mahnke, and D. Muscatine for laboratory assistance; R. Kinzie and the staff of HIMB for loan of facilities and equipment; the National Science Foundation (OCE 8723090) and Office of Naval Research (N00014-89-J3246) for research support; and R. Gates, C. Taylor, and V Weis for reviewing early drafts of the manuscript.

\section{LITERATURE CITED}

Alkon, D. L., Rasmussen, H. (1988). A spatial-temporal model of cell activation. Science 239: 998-1044

Brown, B. E., Suharsono (1990). Damage and recovery of coral reefs affected by EI Nino related seawater warming in the Thousand Islands, Indonesia. Coral Reefs 8: 63-170 
Clark, K. B., Jensen, K. R. (1982). Effects of temperature on carbon fixation and carbon budget partitioning in the zooxanthellae symbiosis of Aiptasia pallida. J. exp. mar. Biol. Ecol. 64: 215-230

Coles, S. J., Fadlallah, Y H. (1990). Reef coral survival and mortality at low temperatures in the Arabian Gulf: new species-specific lower temperature limits. Coral Reefs 9: 231-237

Cook, C. B., Logan, A., Ward, J., Luckhurst, B., Berg, C. J. (1990). Elevated temperatures and bleaching on a high latitude coral reef: the 1988 Bermuda event. Coral Reefs 9 . $45-90$

Cornell, R. G., Speckman, J. A. (1967). Estimation for a simple exponential model. Biometrics 23: 717-737

D'Elia, C. F., Wiebe, W J. (1990). Biogeochemical nutrient cycles in coral reef ecosystems. In: Dubinsky, Z. (ed.) Ecosystems of the world, Vol. 25, Coral reefs. Elsevier, Amsterdam, p. 49-74

Drew, E. A. (1972). The biology and physiology of algainvertebrate symbioses. II. The density of symbiotic algal cells in a number of hermatypic corals and alcyonarians from various depths. J. exp. mar. Biol. Ecol. 9: 71-75

Dubinsky, Z., Stambler, N., Ben-Zion, M., McCloskey, L., Muscatine, L., Falkowski, P. G. (1990). Effect of external nutrient resources on the optical properties and photosynthetic efficiency of Stylophora pistillata. Proc. R. Soc. (Ser. B) 239: 231-246

Gates, R. D. (1990). Seawater temperature and sublethal coral bleaching in Jamaica. Coral Reefs 8: 193-198

Glider, W V., Phipps, D., Pardy, R. L. (1980). Localization of symbiotic dinoflagellate cells within tentacle tissue of Aiptasia pallida (Coelenterata, Anthozoa). Trans. Am. Microsc. Soc. 99: 426-438

Glynn, P. (1977). Coral growth in upwelling and non-upwelling areas off the Pacific coast of Panama. J. mar Res. 35: $567-585$

Glynn, P., D'Croz, L. (1990). Experimental evidence for high temperature stress as the cause of El Nino-coincident coral mortality. Coral Reefs 8: 181-192

Glynn, P., Stewart, R. H. (1973). Distribution of coral reefs in the Pearl Islands (Gulf of Panama) in relation to thermal conditions. Limnol. Oceanogr. 18: 367-379

Goreau, T J., Macfarlane, A. H. (1990). Reduced growth rate of Montastrea annularis following the 1987-1988 coralbleaching event. Coral Reefs 8: 211-216

Harriot, V J. (1985). Mortality rates of scleractinian corals before and during a mass bleaching event. Mar. Ecol. Prog. Ser. 21: 81-88

Hoegh-Guldberg, O. (1989). The regulatory biology of plantanimal endosymbiosis. Ph.D. thesis, University of California, Los Angeles

Hoegh-Guldberg, O., Smith, G. J. (1989). Influence of the population density of zooxanthellae and supply of ammonium on the biomass and metabolic characteristics of the reef corals Seriatopora hystrix and Stylophora pistillata. Mar Ecol. Prog. Ser. 57: 173-186

Jaap, W. (1979). Observations on zooxanthellae expulsion at Middle Sambo Reef, Florida Keys. Bull mar Sci. 29: $414-422$

Jeftrey, S. W., Humphrey, G. F. (1975). New spectrophotometric equations for determining chlorophylls $a, b, c$, and $c_{2}$ in higher plants, algae and natural phytoplankton. Biochem. Physiol. Pfl. 167: 191-194

Jokiel, P. L., Coles, S. L. (1977). Effects of temperature on the mortality and growth of Hawaiian reef corals. Mar. Bıol. 43: 201-208

Jokiel, P. L., Coles, S. L. (1990). Response of Hawaiian and other Indo-Pacific reef corals to elevated temperature. Coral Reefs 8: 155-162

Lasker, H. R., Peters, E. C., Coffroth, M. A. (1984). Bleaching of reef coelenterates in the San Blas Islands, Panama. Coral Reefs 3: $183-190$

Lagunoff, D., Wan, H. (1974). Temperature dependence of mast cell histamine secretion. J. Cell Biol. 61 809-811

Lesser, M. P., Stochaj, W R., Tapley, D. W., Shick, J. M (1990). Bleaching in coral reef anthozoans: effects of irradiance, ultraviolet radiation, and temperature on the activities of protective enzymes against active oxygen Coral Reefs 8: 225-232

Marsh, J. A. (1970). Primary productıvity of reef-building calcareous red algae. Ecology 51: 255-263

Mayer, A. G. (1914). The effects of temperature on tropical marine animals. Car. Inst. Wash. Pap. Tort. Lab. 6: 1-24

Mayer, A. G. (1916). The lower temperature at which reef corals lose their ability to capture food. Yb. Carnegie Instn Wash. 14: 212

Meints, R. H., Pardy, R. L. (1980). Quantitative demonstration of cell surfacement involvement in a plant-animal symbiosis: lectin inhibition of reassociation. J. Cell Sci. 43 239-251

Melchior, D., Steim, J. M. (1976). Thermotropic transitions in biomembranes. A. Rev. Biophys. Bioeng. 5: 205-238

Muscatine, L. (1990). The role of symbiotic algae in carbon and energy flux in reef corals. In: Dubinsky, $Z$. (ed.) Ecosystems of the world, Vol. 25, Coral reefs. Elsevier, Amsterdam, p. 75-87

Muscatine, L., Falkowski, P. G., Dubinsky, Z, Cook, P. A. McCloskey, L. R. (1989). The effect of external nutrient resources on the population dynamics of zooxanthellae in a reef coral. Proc. R. Soc. Lond. B 236: 311-324

Muscatine, L., Wilkerson, F. P., McCloskey, L. R. (1986) Regulation of population density of symbiotic algae in a tropical marine jellyfish (Mastigias sp.). Mar. Ecol. Prog. Ser 32: 279-290

Novozhilov, A., Tsukurov, I., Chernova, Y., Denisov, V. Propp, L. (1992). Gale fluctuations of water temperature at Coetive Island, Seychelles, in January, 1989. Atoll Res. Bull. (in press)

Porter, J. W. (1986). Species profiles: life histories and environmental requirements of coastal fishes and invertebrates (Gulf of Mexico) - reef building corals. U.S. Fish Wildl. Serv. Biol. Rep. US Army Corps of Engineers, TR 85

Porter, J. W., Battey, J. F., Smith, G. J. (1982). Perturbation and change in coral reef communities. Proc. natn. Acad. Sci. U.S.A. 79: 1678-1681

Porter, J. W., Fitt, W. K., Spero, H. J., Rogers, C. S., White, M. W (1989). Bleaching in reef corals: physiological and stable isotope responses. Proc. natn. Acad. Sci. U.S.A. 86 9342-9346

Quinn, P. J. (1989). Principles of membrane stability and phase behavior under extreme conditions. J. Bioenergetics Biomembranes 21: 3-19

Roberts, H. H., Rouse, L. J., Jr, Walker, N. D., Hudson, J. H. (1982). Cold-water stress in Florida Bay and Northern Bahamas: a product of winter cold air outbreaks. J. sedim. Petrol. 52: 145-155

Shinn, E. A. (1966). Coral growth rate, an environmental indicator. J. Paleontol. 40: 233-240

Shinn, E. A. (1976). Coral reef recovery in Florida and the Persian Gulf. Envir Geol. 1: 241-254

Steen, R. G., Muscatine, L. (1987). Low temperature evokes rapid exocytosis of symbiotic algae by a sea anemone. Biol. Bull. mar. biol Lab., Woods Hole 172: 246-263 
Stimson, J., Kinzie, R. A. (1991). Temporal pattern and release rate of zooxanthellae from the reef coral Pocillopora damicornis (Linnaeus) under nitrogen enrichment and control conditions. J. exp. mar Biol. Ecol. (In press)

Szmant, A., Gassman, N. J. (1990). The effects of prolonged 'bleaching on the tissue biomass and reproduction of the reef coral Montastrea annularis. Coral Reefs 8: 217-224

Walker, N. D., Roberts, H. H., Rouse Jr, L. J., Huh, O. K. (1982). Thermal history of reef-associated environments

This article was submitted to the editor during a record cold-air outbreak event. Coral Reefs 1: $83-87$

Watson, P. F., Morris, G. J. (1987). Cold shock injury in animal cells. Symp. Soc. exp. Biol. 41 311-340

Williams, E. H. Jr, Bunkley-Williams, L. (1990). The worldwide coral reef bleaching cycle and related sources of coral mortality. Atoll Res. Bull. 335: 1-71

Zar, J. H. (1984). Biostatistical analysis. Prentice Hall International, London

Manuscript first received: May 10, 1991

Revised version accepted: August 22, 1991 